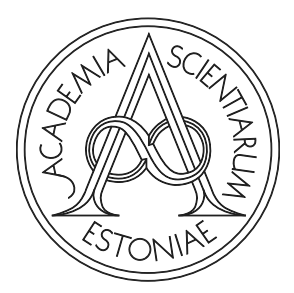

Proceedings of the Estonian Academy of Sciences, $2021, \mathbf{7 0}, 4 \mathrm{~S}, 310-316$

https://doi.org/10.3176/proc.2021.4S.01

Available online at www.eap.ee/proceedings

AMBLYOPIA

TREATMENT

\title{
The use of specialized computer games for the treatment of amblyopia in Latvia
}

\author{
Kristine Kalnica-Dorosenko ${ }^{\mathrm{a}, \mathrm{b}^{*}}$, Sandra Valeina ${ }^{\mathrm{a}}$, Aiga Svede ${ }^{\mathrm{b}}$ and Gunta Krumina ${ }^{\mathrm{b}}$ \\ ${ }^{a}$ Eye Diseases Clinic, Children's Clinical University Hospital, Vienibas gatve 45, LV-1004, Riga, Latvia \\ ${ }^{\mathrm{b}}$ Department of Optometry and Vision Science, University of Latvia, Jelgavas iela 1, LV-1004, Riga, Latvia
}

Received 1 November 2020, accepted 31 March 2021, available online 27 September 2021

(C) 2021 Authors. This is an Open Access article distributed under the terms and conditions of the Creative Commons AttributionNonCommercial 4.0 International License (http://creativecommons.org/licenses/by-nc/4.0/).

\begin{abstract}
The classical treatment option for amblyopia in Latvia is occlusions of the non-amblyopic eye. The newest methods involve specialized computer games that involve both eyes in visual processing during the treatment as well as stimulate binocularity. To assess the efficiency of specialized computer games in the treatment of amblyopia in school-age children in Latvia, 237 children (718 years old) participated in the experiment, of whom only 22 completed it: 11 participants had occlusion therapy, 11 participants played the specialized dichoptic computer game Tetris ${ }^{\circledR}$. The visual acuity of the amblyopic eye as well as stereopsis were evaluated at near and far distances before the treatment, 2 months and 4 months after the beginning of the treatment. The results show statistically significant improvement in visual acuity in both treatment groups after four months of therapy. The extent of improvement is similar in both groups. Specialized computer games for amblyopia treatment may be recommended to patients from an age when they are able to use a computer along with a keyboard and computer mouse, who want to improve their visual acuity in the amblyopic eye but are not willing to use occlusions. The only requirement for using specialized games is that the patients need to have binocular single vision. In conclusion, the use of specialized computer games is an alternative type of amblyopia treatment compared to occlusion therapy.
\end{abstract}

Key words: amblyopia, specialized computer games, occlusions, amblyopia treatment, stereovision.

\section{INTRODUCTION}

Amblyopia or "lazy" eye is a disorder of the early development of the brain cells, not a disorder in the development of the eye itself [1]. The information sent by the "lazy" eye cannot compete with the other (betterseeing) eye information, which in turn weakens the development of the brain cells receiving information from the amblyopic eye. Thus, amblyopia is a disorder that mainly affects children. The prevalence of amblyopia in literature is varying from $0.7 \%$ to $5 \%$, depending on the location of the study, population characteristics, criteria for visual acuity, and visual acuity evaluation methods [2-10]. In Latvia the preva-

\footnotetext{
*Corresponding author, kristinekalnica@gmail.com
}

lence of amblyopia in the region of Riga is $2.3 \%$, in Riga $1.6 \%[11]$.

Amblyopia is mainly associated with strabismus, anisometropia, combined amblyopia (anisometropia with strabismus), and less commonly with congenital cataracts or ptosis [12]. In Latvia, among the types of amblyopia the most dominant are strabismic and refractive amblyopia [11]. If amblyopia has not been treated successfully in childhood, it can cause constant visual disturbance [13]. Most eye specialists in Latvia end the treatment of amblyopia when a child has reached the age of 7-8 years. However, recent studies have shown that adults can still improve their visual acuity in the amblyopic eye [14-18].

The main task of amblyopia treatment is to ameliorate etiological factors to create a clear retinal image, to ensure the participation of the amblyopic eye in the visual 
process, and to normalize binocular functions. One of the primary and classic methods of amblyopia treatment in Latvia is a non-amblyopic eye occlusion for a specified period of time [19], but it does not contribute to the regeneration and development of binocular functions. Therefore, methods have been developed that involve both eyes in the visual process and stimulate their cooperation (binocularity). The non-amblyopic eye occlusion or passive amblyopia treatment may be combined or perhaps replaced by a more active form of treatment such as specialized computer games. The reason for this new method is that the patient will be more involved (attentive) and will actively participate in the therapy [20]. Also, a successful performance of the task will only be possible if the patient uses both eyes even if the main role is focused on the amblyopic eye [21]. It stimulates the involvement of the amblyopic eye in the visual processing and development of the brain cells. As a result, the activation of the brain cells - both monocular (receiving information from the amblyopic eye) and binocular - will result in the improvement of visual acuity in the amblyopic eye.

The use of specialized computer games in amblyopia is being studied as an alternative treatment for amblyopia in patients [18,22-25]. In Latvia, no vision specialists have yet resorted to specialized computer games in the treatment of amblyopia. We were interested to examine how this amblyopia treatment would affect patients between the age of 7 and 18 years, when the visual system's plasticity is even higher than that of adults, but significantly reduced compared to the plasticity of the visual system of pre-school children. The intention was also to learn whether this form of treatment would be of interest to children after the age of seven who reject ocular therapy wholeheartedly. The aim of the study was to assess the efficiency of specialized computer games in the treatment of amblyopia for Latvian school-age children (the first study of its kind). It was expected that for schoolage children both methods - non-amblyopic eye occlusion and a specialized computer game - would provide the same improvement in visual acuity, and the efficiency of both methods would be comparable. Using a simple and accessible Tetris game design was considered sufficient to achieve effectiveness in treating amblyopia.

\section{MATERIALS AND METHODS}

In cooperation with ophthalmologists, 237 patients with amblyopia were examined for the first time at the Eye Diseases Clinic of Children's Clinical University Hospital in Riga, Latvia. 52 participants met the selection criteria, but only 22 participants with anisometropic $(n=14)$, strabismic (intermittent exotropia) $(n=3)$, and combined $(n=5)$ amblyopia completed the treatment to the end (see Fig.1).

Main criteria for selecting participants in the experiment: the difference between eyes of at least two lines; the age of participants from 7 to 18 years; the presence of binocular vision; overall and neurologically healthy children. Evaluation of visual acuity: best corrected visual acuity; monocular vision test at near and far; all open lines of optotypes were demonstrated (a visual acuity test with individual optotypes was eliminated to avoid a crowding effect). Evaluation of suppression: Bagolini striated glasses test. Evaluation of stereovision: TNO test at near and Osterberg test at far; for participants who had a negative TNO test, stereovision was tested at

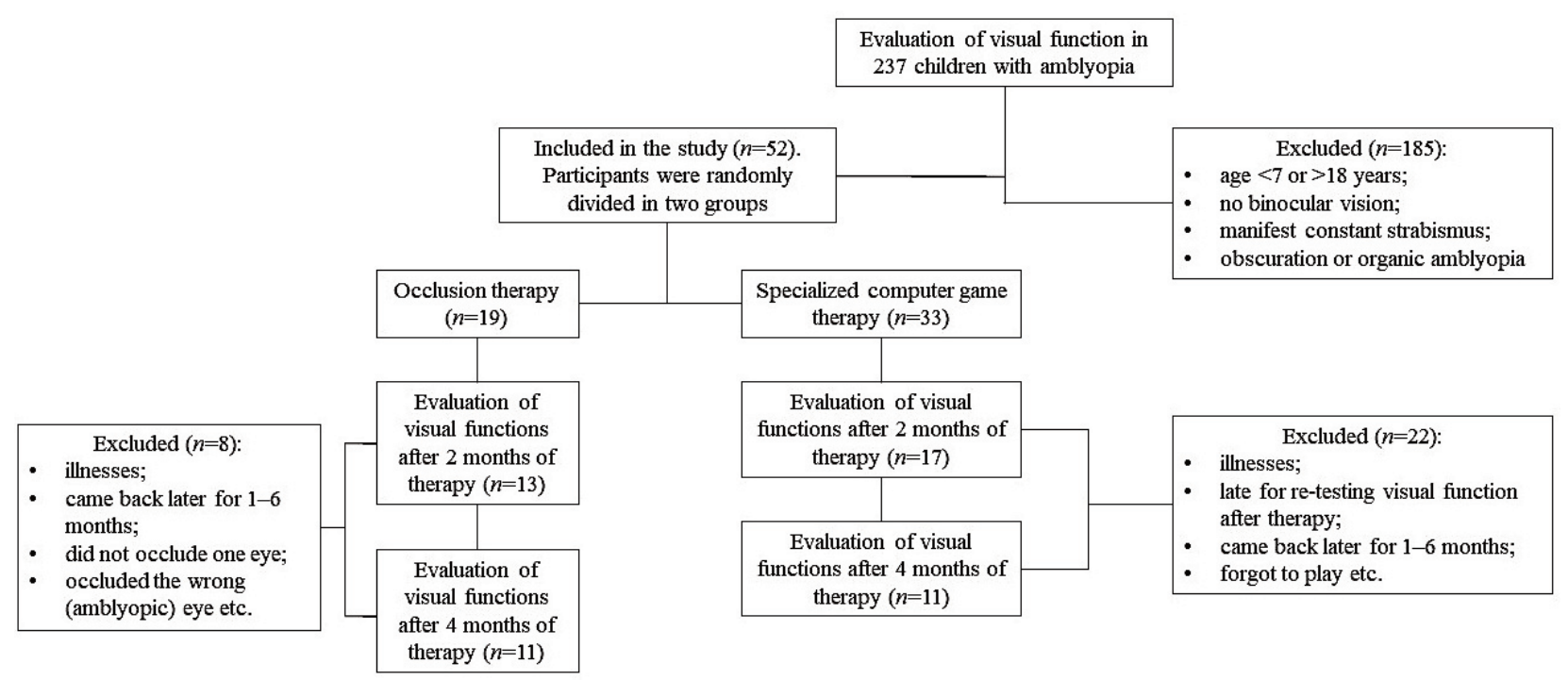

Fig. 1. Flowchart of the selection process and treatment process over a period of 4 months. 
near with the Titmus test or the Lang two-pencil test, but the results were not reflected in the analysis. Evaluation of strabismus angle: Hirschberg test, cover-uncover test, alternate cover test, prism alternate cover test.

The participants were randomly divided in two groups, but before that the children had to wear glasses that were prescribed (after cycloplegia) after the first visit, 1-3 months. Group O: participants who had occlusion therapy - 11 participants (O1-O11), the average age was $8 \pm 1$ years (from 7 to 10 years) and the average occlusion time was $5 \pm 2$ hours per day (according to parents). Parents were told that the better-seeing eye should be occluded for 2 to 4 hours every day. Additionally, parents were shown at the eye specialist's office how to close the betterseeing eye correctly and were explained why this should be done. Group S: participants who played the specialized computer game at home - 11 participants (S1-S11), the average age was $10 \pm 3$ years (from 7 to 15 years) and the average playing time was $36 \pm 16$ min per day (according to parents). Parents were told that children should play a specialized computer game for 25 minutes a day. Each parent was emailed instructions on where and how to download and install the game, as well as how to play it properly. The timing of the therapy was monitored and documented by parents and patients.

One participant (S1) had congenital lens opacities in the periphery, which did not bother him at all (the cause of amblyopia was anisometropia). Two participants (S5 and S6) had occlusions before the age of seven but stopped occlusions because there was no improvement in visual acuity in the amblyopic eye. In addition, two children (7 and 10 years old) (control group) without amblyopia and other visual problems played the specialized computer game for amblyopia treatment to evaluate the effect of the game on normal visual functions. The average playing time was $25 \pm 5 \mathrm{~min}$ per day.

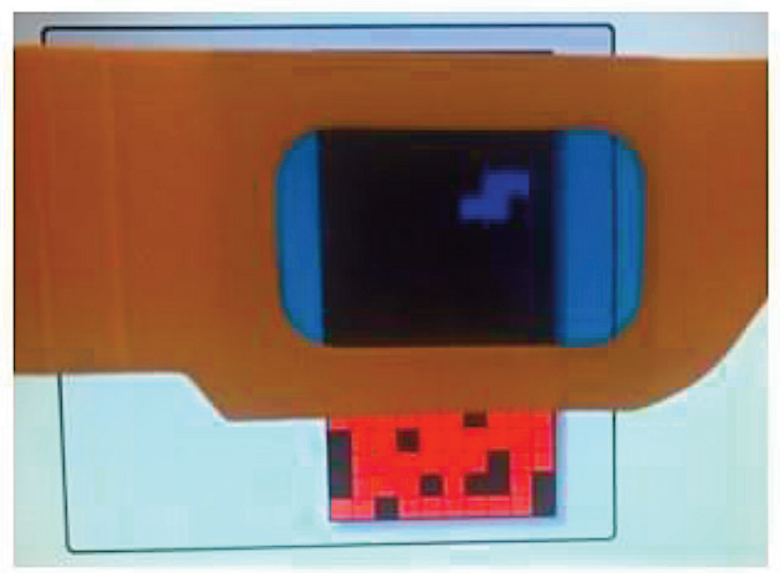

Comparing the two groups of participants (the group of participants who occluded one eye and the group of participants who played a specialized computer game for the treatment of amblyopia) both in terms of age $(p=.25)$ and visual acuity in the amblyopic eye and the degree of severity of amblyopia $(p=.94)$, no statistically significant differences were observed (non-parametric Mann-Whitney U test).

All procedures were carried out in accordance with the tenets of the Declaration of Helsinki and were approved by the Ethics Committee of Experimental and Clinical Medicine Institute of the University of Latvia. Informed consent was obtained from all patients and their parents prior to data collection.

\subsection{Study protocol}

All children had full eye examination before the treatment. Visual acuity and stereovision for near (TNO test) and far (Osterberg test) were evaluated 2 and 4 months after the beginning of the treatment. During the eye examination as well as during the treatment, all participants used their best optical correction. The examination of visual acuity (in decimal units) was performed with the whole line of optotypes to keep the crowding effect.

We used a specialized computer game Tetris ${ }^{\circledR}$ developed for the treatment of amblyopia. All participants in group $\mathrm{S}$ received the same red-blue glasses and installed the free online game on their home computers (http://www.strabismusworld.com/practical/free-antisuppression-tetris/). It was also necessary to change the settings in the computer and calibrate the screen contrast. In the Tetris ${ }^{\circledR}$ game, red-blue glasses separate individual game elements - each eye sees its own stimulus. The nonamblyopic eye sees blue stimuli with low contrast, while the amblyopic or "lazy" eye sees red stimuli with high contrast (see Fig. 2). Combining information from both

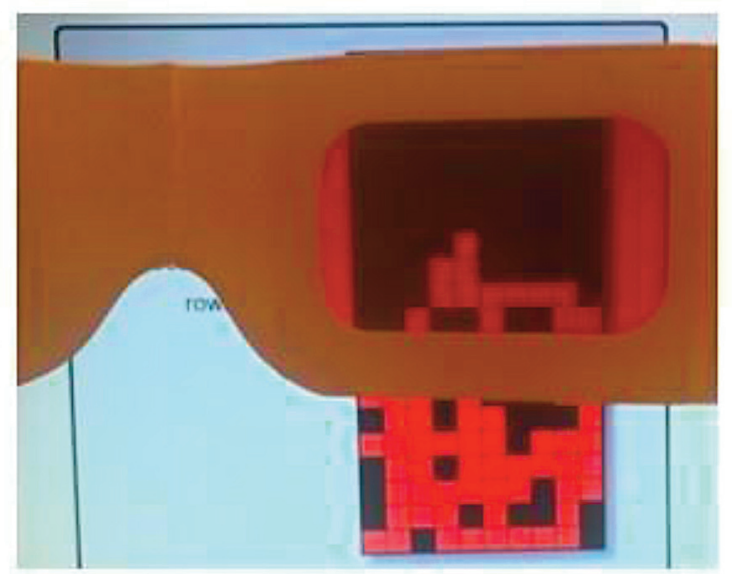

Fig. 2. Red-blue filters separate Tetris ${ }^{\circledR}$ game elements. For example, the amblyopic eye is the right eye. The blue falling blocks are seen by the non-amblyopic eye (the left eye) in low contrast conditions, while red base blocks are seen by the amblyopic eye (the right eye) in high contrast conditions. 
eyes creates the full image of the game and allows the participant to complete the task of the game: to move and rotate downward falling blocks to fill in all the rows. If an entire row is filled in, it will disappear. All participants tried the game in an optometrist office and received playing instructions for home therapy.

\subsection{Data analysis}

Due to the small number of participants in each group, we applied nonparametric statistical methods. Wilcoxon signed-rank test was used to evaluate within-subject changes of visual acuity of the amblyopic eye, as well as changes in near stereoacuity before and after four months of treatment. Mann-Whitney U test was performed to compare the efficacy of occlusion and specialized computer game therapy.

\section{RESULTS}

After two months of training, using occlusion and specialized computer games, the visual acuity in the amblyopic eye improved statistically significantly in the two groups (Wilcoxon signed-rank test, $p<.05$ ). MannWhitney $U$ test analysis demonstrates that there is no statistical difference between both groups; the group mean improvement in visual acuity was similar in the two groups. The training continued for another two months afterwards to further improve the results in the amblyopic eye.

After four months of occlusion therapy, 6 participants improved visual acuity in the amblyopic eye at far (see
Table 1), and 4 participants had no improvement in visual acuity. Eight participants improved visual acuity in the amblyopic eye at near, 2 participants had no changes in visual acuity (see Table 1), and 1 participant (O6) had no improvement in visual acuity either for near or for far. After four months of occlusions, the visual acuity even decreased due to the scratched spectacle lenses. The overall improvement in visual acuity in the occlusion group was statistically significant, visual acuity improved on average by $2 \pm 0.12$ lines (on the decimal number chart) (Wilcoxon signed-rank test $Z=-2.19, p<.05$ ).

After four months of specialized computer game therapy, 9 participants improved visual acuity in the amblyopic eye at far (see Table 2), and only 2 participants had no changes in visual acuity. All participants improved visual acuity in the amblyopic eye at near (see Table 2). Even in this group, the overall improvement in visual acuity was statistically significant, visual acuity improved on average by $2 \pm 0.06$ lines (on the decimal number chart) (Wilcoxon signed-rank test, $\mathrm{Z}=2.67, p<.05$ ). MannWhitney $U$ test analysis demonstrates that there is no statistical difference between both groups either for far (two-sided $p$-value, $p=.84$ ) or for near (two-sided $p$ value, $p=.34)$; the group mean improvement in visual acuity was similar in both groups. Patients who did not improve their visual acuity in the amblyopic eye after 4 months from the start of the training continued therapy.

Before the treatment, stereovision was observed only in 13 participants with anisometropic amblyopia (see Fig. 3): 3 in the group with occlusion therapy and 10 in the group playing the specialized computer game.

Stereoacuity at near significantly improved after four months of treatment (Wilcoxon signed-rank test, $p<.05$ ).

Table 1. Visual acuity evaluation results for far and near in participants with occlusion therapy before, 2 months and 4 months after the beginning of amblyopia therapy

\begin{tabular}{l|c|c|c|c|c|c|c}
\hline & Age, years & \multicolumn{3}{|c|}{$\begin{array}{c}\text { Far } \\
\text { Visual acuity, decimal units }\end{array}$} & \multicolumn{3}{c}{ Visual acuity, decimal units } \\
\cline { 3 - 8 } & & Before & $\begin{array}{c}\text { After 2 } \\
\text { months }\end{array}$ & $\begin{array}{l}\text { After 4 } \\
\text { months }\end{array}$ & Before & $\begin{array}{c}\text { After 2 } \\
\text { months }\end{array}$ & $\begin{array}{c}\text { After 4 } \\
\text { months }\end{array}$ \\
\hline O1 & 7 & 0.5 & 0.8 & 1.0 & 0.6 & 1.0 & 1.0 \\
O2 & 7 & 0.6 & 0.9 & 1.0 & 0.6 & 1.0 & 1.0 \\
O3 & 8 & 0.4 & 0.8 & 1.25 & 0.6 & 1.0 & 1.0 \\
O4 & 8 & 0.8 & 0.8 & 0.8 & 0.8 & 0.8 & 0.8 \\
O5 & 8 & 0.12 & 0.12 & 0.12 & 0.16 & 0.2 & 0.2 \\
O6 & 8 & 0.16 & 0.16 & 0.12 & 0.25 & 0.25 & 0.1 \\
O7 & 7 & 0.8 & 0.8 & 0.8 & 0.6 & 0.8 & 0.8 \\
O8 & 9 & 0.5 & 0.5 & 0.6 & 0.5 & 0.5 & 0.5 \\
O9 & 8 & 0.7 & 0.8 & 1.0 & 0.6 & 0.6 & 1.0 \\
O10 & 10 & 0.8 & 0.8 & 0.8 & 0.6 & 0.6 & 0.8 \\
O11 & 7 & 0.5 & 1.0 & 1.0 & 0.5 & 0.6 & 1.0
\end{tabular}


Table 2. Visual acuity evaluation results for far and near in participants with specialized computer game therapy before, 2 months and 4 months after amblyopia therapy

\begin{tabular}{l|c|c|c|c|c|c|c}
\hline & Age, years & \multicolumn{3}{|c|}{$\begin{array}{c}\text { Far } \\
\text { Visual acuity, decimal units }\end{array}$} & \multicolumn{3}{c}{ Visual acuity, decimal units } \\
\cline { 3 - 7 } & & Before & $\begin{array}{c}\text { After 2 } \\
\text { months }\end{array}$ & $\begin{array}{c}\text { After 4 } \\
\text { months }\end{array}$ & Before & $\begin{array}{c}\text { After 2 } \\
\text { months }\end{array}$ & $\begin{array}{c}\text { After 4 } \\
\text { months }\end{array}$ \\
\hline S1 & 15 & 0.6 & 1.0 & 1.0 & 0.8 & 1.0 & 1.0 \\
S2 & 7 & 0.8 & 0.8 & 0.8 & 0.8 & 1.0 & 1.0 \\
S3 & 12 & 0.8 & 1.0 & 1.0 & 0.8 & 1.0 & 1.0 \\
S4 & 9 & 0.5 & 0.5 & 0.5 & 0.6 & 0.8 & 1.0 \\
S5 & 12 & 0.2 & 0.4 & 0.4 & 0.3 & 0.5 & 0.5 \\
S6 & 13 & 0.3 & 0.4 & 0.4 & 0.3 & 0.8 & 0.8 \\
S7 & 7 & 0.6 & 0.8 & 0.8 & 0.6 & 0.8 & 0.8 \\
S8 & 7 & 0.4 & 0.4 & 0.5 & 0.5 & 0.5 & 0.8 \\
S9 & 7 & 0.7 & 0.8 & 1.0 & 0.8 & 1.0 & 1.0 \\
S10 & 18 & 0.8 & 0.8 & 1.0 & 0.6 & 0.8 & 1.0 \\
S11 & 10 & 0.6 & 0.8 & 1.0 & 0.6 & 0.8 & 1.0
\end{tabular}

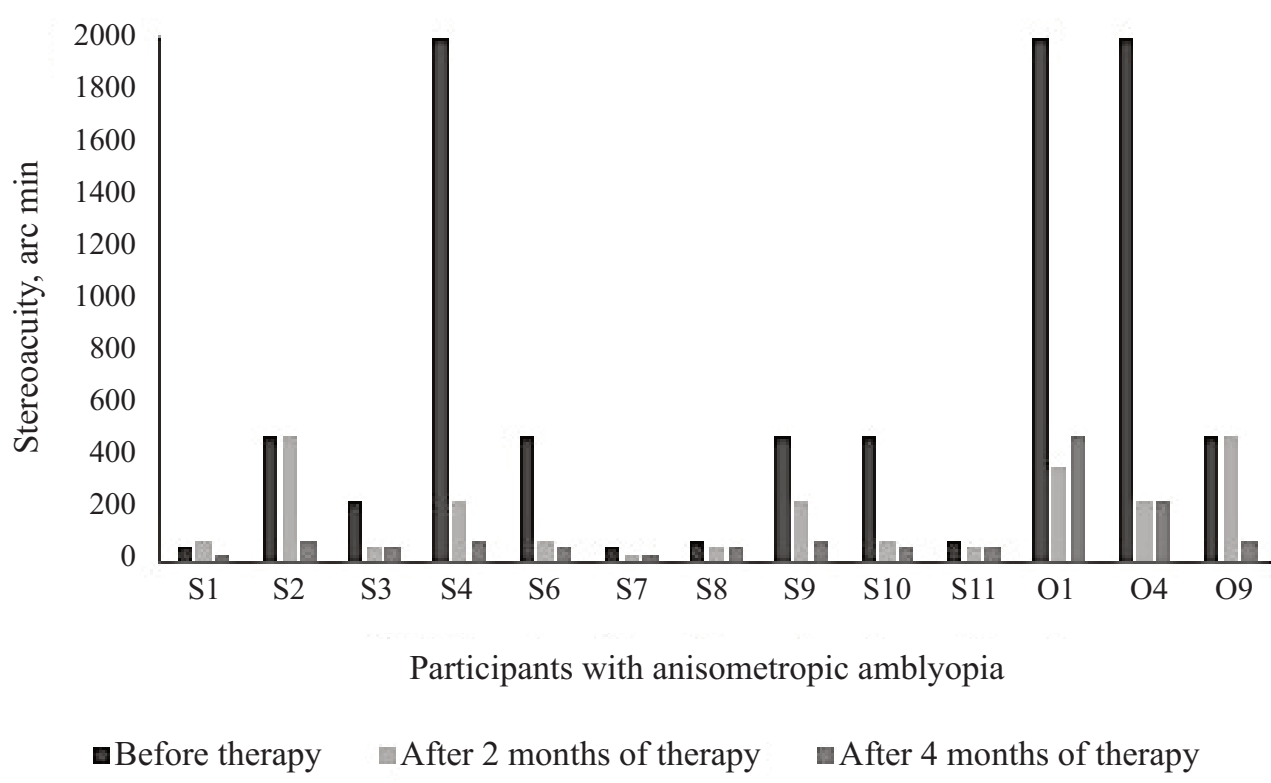

Fig. 3. Stereoacuity of participants with anisometropic amblyopia at near before, 2 months and 4 months after amblyopia therapy.

However, stereovision at far remained only in participants having stereovision also before the treatment ( 7 participants).

\section{DISCUSSION}

The study explored the efficiency of a specialized computer game in amblyopia treatment compared to the classical amblyopia treatment method - occlusion of the non-amblyopic eye. The results show that visual acuity improved equally in the group of patients with occlusion therapy and in the group playing a specialized computer game. Thus, the use of specialized computer games in amblyopia therapy is an effective and rapid way of treating patients after the age of seven. In addition, more patients (10 out of 11) from the group playing a specialized computer game improved their stereoacuity at near. Our results support the observations of other authors that the participants who played specialized computer games improved visual acuity in the amblyopic eye $[16,18,26-28]$ as well as improved stereovision 
[16,18,26-28]. Birch et al. [29] and Kelly et al. [24] described a slightly different result. They observed improvements of visual acuity in the amblyopic eye, but stereovision did not change $[24,29]$.

Hess et al. [28] emphasized that dichoptic vision perception is intended to strengthen binocular functions by reducing suppression, improving stereovision and visual acuity in children and adults with amblyopia [28]. However, not all participants of our study improved stereovision due to low visual acuity in the amblyopic eye (and large difference between both eyes). Strong suppression is associated with low monocular visual acuity [17]. Therefore, binocular functions and stereovision are difficult to achieve.

The study involved two children with no visual problems to assess the effect of a specialized computer game on normal visual functions. Unfortunately, one child (7 years old) discontinued participation due to the lack of motivation and difficulties in using the keyboard (not seeing the arrows through the red-blue glasses). The other child (10 years old) played the specialized computer game for the entire four months. There were no changes in visual acuity and stereoacuity. The participant admitted that it was difficult to motivate herself to play the game every day because there were no complaints about visual functions.

One of the main challenges was trusting the patients' parents and their attitude towards the treatment, because we could only rely on their word that the therapy had been carried out - for example, in situations where visual acuity did not improve after therapy. Was it because the correct refractive correction was not prescribed or because a particular method of therapy was not suitable for the patient or because it was not performed at home, even though the parents said that the treatment had been carried out? All of these issues encourage further improvement in the methodology for amblyopia therapy by using specialized computer games.

\section{CONCLUSIONS}

Specialized computer game therapy can be recommended to patients from an age when they are able to use a computer along with a keyboard and computer mouse, who want to improve their visual acuity in the amblyopic eye (also after the age of seven). The only condition for using this game would be the existence of binocular vision as without binocular vision the dichoptic visual tasks designed for the treatment are impossible. Making use of the simple and accessible design of the specialized computer game Tetris is sufficient to achieve effectiveness in the treatment of amblyopia. Although the treatment of amblyopia through binocularity involvement like in specialized computer games and video games is still not extensively used in the medical environment, it is an effective, modern, and enjoyable method for amblyopia patients. Our study has limitations due to a small sample size; however, our results are sufficient to conclude that the use of specialized computer games for the treatment of amblyopia is an alternative type of amblyopia treatment compared to occlusion therapy. By improving the amblyopic eye training methodology by means of specialized computer games, a large number of patient dropouts can be avoided, a decrease in motivation can be avoided, and the actual results of patients, rather than those reported by parents, can be monitored more carefully.

\section{ACKNOWLEDGEMENT}

This study received no specific grant from any funding from the public or commercial sectors. The publication costs of this article were partially covered by the Estonian Academy of Sciences.

\section{REFERENCES}

1. Rouse, M. W., Cooper, J. S., Cotter, S. A., Press, L. J. and Tannen, B. M. Care of the Patient with Amblyopia: Reference Guide for Clinicians. American Optometric Association, 1994.

2. Von Noorden, G. K. and Campos, E. C. Binocular Vision and Ocular Motility. 6th ed. Mosby, St. Louis, MO, 2002.

3. Grönlund, M. A., Andersson, S., Aring, E., Hård, A.-L. and Hellström, A. Ophthalmological findings in a sample of Swedish children aged 4-15 years. Acta Ophthalmol. Scand., 2006, 84(2), 169-176.

4. Robaei, D., Kifley, A., Gole, G. A. and Mitchell, P. The impact of modest prematurity on visual function at age 6 years: findings from a population-based study. Arch. Ophthalmol., 2006, 124(6), 871-877.

5. Robaei, D., Rose, K. A., Ojaimi, E., Kifley, A., Martin, F. J. and Mitchell, P. Causes and associations of amblyopia in a population-based sample of 6-year old Australian children. Arch. Ophthalmol., 2006, 124(6), 878-884.

6. Sapkota, Y. D., Adhikari, B. N., Pokharel, G. P., Poudyal, B. K. and Ellwein, L. B. The prevalence of visual impairment in school children of upper-middle socioeconomic status in Kathmandu. Ophthalmic Epidemiol., 2008, 15(1), 17-23.

7. Shrestha, G. S., Sujakhu, D. and Joshi, P. Refractive error among school children in Jhapa, Nepal. J. Optom., 2011, 4(2), 49-55.

8. Mazarei, M., Fard, M. A., Merat, H. and Roohipoor, R. Associations of refractive amblyopia in a population of Iranian children. J. Optom., 2013, 6(3), 167-172.

9. Bhandari, G., Byanju, R. and Kandel, R. P. Prevalence and profile of amblyopia in children at Bharatpur eye hospital. J. Paediatr. Child Health, 2015, 3(8), 1085. 
10. Sushil, O., Meenu, B., Vaibhav, J., Reena, S., Brijesh, S. and Singh, S. Pattern of refractive error in paediatric patients coming to rural tertiary care hospital of Central India. Indian J. Clin. Exp. Ophthalmol., 2016, 2(1), 72-75.

11. Dzenite, B. Prevalence of amblyopia types. Bachelor thesis. University of Latvia, Riga, Latvia, 2007.

12. Wong, A. M. F. New concepts concerning the neural mechanisms of amblyopia and their clinical implications. Can. J. Ophthalmol., 2012, 47(5), 399-409.

13. Parks, M. M. Treatment of the sensorial adaptations and amblyopia. In Clinical Ophthalmology, vol. 1 (Duane, T. D., ed.). Harper and Row, Hagerstown, MD, 1989, 1-14.

14. Baroncelli, L., Maffei, L. and Sale, A. New perspectives in amblyopia therapy on adults: a critical role for the excitatory/inhibitory balance. Front. Cell. Neurosci., 2011, 5(25), $1-6$.

15. Astle, A. T., McGraw, P. V. and Webb, B. S. Can human amblyopia be treated in adulthood? Strabismus, 2011, 19(3), 99-109.

16. Spiegel, D. P., Li, J., Hess, R. F., Byblow, W. D., Deng, D., Yu, M. and Thompson, B. Transcranial direct current stimulation enhances recovery of stereopsis in adults with amblyopia. Neurotherapeutics, 2013, 10(4), 831-839.

17. Hess, R. F. and Thompson, B. Amblyopia and the binocular approach to its therapy. Vision Res., 2015, 114, 4-16.

18. Žiak, P., Holm, A., Halička, J., Mojžiš, P. and Piñero, D. P. Amblyopia treatment of adults with dichoptic training using the virtual reality oculus rift head mounted display: preliminary results. BMC Ophthalmol., 2017, 17(1), 105.

19. Loudon, S. E. and Simonsz, H. J. The history of the treatment of amblyopia. Strabismus, 2005, 13(2), 93-106.

20. Webber, A. I., Wood, J. M., Gole, G. A. and Brown, B. Effect of amblyopia on self esteem in children. Optom. Vis. Sci., 2008, 85(11), 1074-1081.

21. Scheiman, M., Hertle, R. W., Beck, R. W., Edwards, A. R., Birch, E. E., Cotter, S. A. et al. Randomized trial of treat- ment of amblyopia in children aged 7 to 17 years. Arch. Ophthalmol., 2005, 123(4), 437-447.

22. Foss, A. J., Gregson, R. M., MacKeith, D., Nicola, H., Ash, I. M., Cobb, S. V. et al. Evaluation and development of a novel binocular treatment (I-BiT $\left.{ }^{\mathrm{TM}}\right)$ system using video clips and interactive games to improve vision in children with amblyopia ('lazy eye'): study protocol for a randomised controlled trial. Trials, 2013, 14, 145.

23. Li, S. L., Jost, R. M., Morale, S. E., Stager, D. R., Dao, L., Stager, D. and Birch, E. E. A binocular iPad treatment for amblyopic children. Eye (Lond), 2014, 28(10), 1246-1253.

24. Kelly, K. R., Jost, R. M., Dao, L., Beauchamp, C. L., Leffler, J. N. and Birch, E. E. Binocular iPad game vs patching for treatment of amblyopia in children: a randomized clininal trial. JAMA Ophthalmol., 2016, 134(12), $1402-1408$.

25. Jeon, S. T., Maurer, D. and Lewis, T. L. The effect of video game training on the vision of adults with bilateral deprivation amblyopia. Seeing Perceiving, 2012, 25(5), 493520.

26. Knox, P. J., Simmers, A. J., Gray, L. S., Cleary, M. An exploratory study: prolonged periods of binocular stimulation can provide an effective treatment for childhood. Investig. Ophthalmol. Vis. Sci., 2012, 53(2), 817-824.

27. Li, J., Thompson, B., Deng, D., Chan, L. Y. L., Yu, M. and Hess, R. F. Dichoptic training enables the adult amblyopic brain to learn. Curr. Biol., 2013, 23(8), 308-309.

28. Hess, R. F., Babu, R. J., Clavagnier, S., Black, J., Bobier, W. and Thompson, B. The iPod binocular home-based treatment for amblyopia in adults: efficacy and compliance. Clin. Exp. Optom., 2014, 97(5), 389-398.

29. Birch, E. E., Li, S. L., Jost, R. M., Morale, S. E., De La Cruz, A., Stager, D. Jr, Dao. L. and Stager, D. R. Sr. Binocular iPad treatment for amblyopia in preschool children. J. AAPOS, 2015, 19(1), 6-11.

\section{Spetsiaalse arvutimängu kasutamine amblüoopiaravis Lätis}

\section{Kristine Kalnica-Dorosenko, Sandra Valeina, Aiga Svede ja Gunta Krumina}

Klassikaline amblüoopiaravi Lätis hõlmab mitteamblüoopse silma kinnikatmist ehk oklusiooni. Uusimad ravimeetodid kasutavad spetsiaalseid arvutimänge, mis hõlmavad visuaalsel töötlusel mõlema silma kasutamist ja stimuleerivad binokulaarset nägemist. Hindamaks spetsiaalse arvutimängu efekti amblüoopiaravis Lätis osales uuringus 237 last vanuses 7-18 eluaastat, neist ainult 22 last viis uuringu lõpuni: 11 last läbis oklusiooniravi ja 11 last mängis spetsiaalset dikoptilist arvutimängu Tetris ${ }^{\circledR}$. Amblüoopse silma nägemisteravust ja stereopsist hinnati nii kaugele kui ka lähedale vaatamisel enne ravi ning kaks ja neli kuud peale sekkumise algust. Tulemused näitavad statistiliselt olulist nägemisteravuse suurenemist mõlemas sekkumisgrupis neli kuud peale teraapiat. Nägemisteravuse suurenemine on sarnane mõlemas grupis. Spetsiaalse arvutimängu kasutamist amblüoopiaravis võib soovitada patsientidele alates east, kui nad on suutelised kasutama arvutit, klaviatuuri ja hiirt ning soovivad parandada oma amblüoopse silma nägemisteravust, kuid ei ole nõus oklusiooniraviga. Ainus eeldus spetsiaalse arvutimängu kasutamisel on binokulaarse nägemise olemasolu. Kokkuvõtteks: spetsiaalsete arvutimängude kasutamine on lisaks oklusiooniteraapiale alternatiivseks meetodiks amblüoopiaravis. 